\title{
Communication Skills in Young Children with Emotional Disorder in Kupang
}

\author{
Beatriks Novianti Kiling-Bunga ${ }^{1}$, \\ Oktovianus Halla ${ }^{2}$, \\ Indra Yohanes Kiling ${ }^{3}$ \\ Teaching and Education Faculty \\ Early Childhood Education Teacher Program \\ Universitas Nusa Cendana \\ JL. Adisucipto, Penfui \\ Kupang 85001, Indonesia \\ ${ }^{1}$ e-mail: boenga.eve@gmail.com \\ ${ }^{2}$ e-mail: oktovianushalla@gmail.com \\ ${ }^{3} e$-mail: iykiling@gmail.com
}

Part of this paper was presented at the International Conference of Early Childhood Education 2014, Universitas Pendidikan Indonesia, 18-19 November 2014 in Bandung

\begin{abstract}
Young children with disabilities are a group that is prone to stigma and discrimination. Therefore, World Health Organization and United Nations Children's Fund declared a global agenda in 2012 to address the needs of inclusive ECCD to improve the participation and development of young children with disabilities. In respond to that agenda, it is crucial to understand the particular needs of young children with emotional disorder such as their communication ability, before they can be included into inclusive ECCD service. This research aims to describe the communication skills of young child with emotional disorder in Kupang, Nusa Tenggara Timur. The participant in this study showed insignificant performance in verbal communication skills like linguistic content, structures and the use of language. Meanwhile in non verbal communication skills such as face expression, body gesture and hand gesture, the child showed considerable performance. The research method used qualitative method, which is direct observation to the child and interview to the subject's parents. Parents and ECCD tutors should consider to set a communicationstimulating relationship in house and ECCD post to support the verbal skills development. The result of this study can give impact in the development of inclusive ECCD science in East Nusa Tenggara, also to aid future research in inventing best practice models in the field.
\end{abstract}

Keywords: communication skills; young children; emotional disorder

Abstrak-Anak-anak penyandang disabilitas merupakan kelompok yang rentan terhadap stigma dan diskriminasi. Oleh karena itu, World Health Organization dan 
United Nations Children's Fund menyatakan suatu agenda global pada tahun 2012 dengan tujuan untuk menangani kebutuhan PAUD inklusif, terutama pada peningkatan partisipasi dan perkembangan kebutuhan tersebut pada anak-anak penyandang cacat. Menanggapi agenda itu, hal pertama yang diperlukan adalah pemahaman akan kebutuhan pada anak-anak berkebutuhan khusus, salah satunya anak dengan gangguan emosional, seperti pemahaman akan kemampuan komunikasi mereka, sebelum mereka dimasukkan ke dalam layanan inklusif. Penelitian ini bertujuan untuk mendapatkan gambaran komunikasi anak-anak dengan gangguan emosional di Kupang, Nusa Tenggara Timur. Partisipan dalam penelitian ini menunjukkan kinerja yang tidak signifikan pada keterampilan komunikasi verbal seperti konten linguistik, struktur, dan penggunaan bahasa. Sementara itu dalam keterampilan komunikasi non-verbal seperti ekspresi wajah, gerakan tubuh, dan gerakan tangan, anak menunjukkan kinerja yang cukup. Pendekatan penelitian yang digunakan adalah pendekatan kualitatif, dengan metode pengumpulan data dengan cara observasi langsung ke subjek dan wawancara kepada orangtua subjek. Orangtua dan guru PAUD harus mempertimbangkan untuk mengatur stimulus-stimulus yang berhubungan dengan pelatihan komunikasi di rumah dan setelah PAUD untuk mendukung pengembangan kemampuan verbal. Hasil penelitian ini bisa memberikan dampak dalam pengembangan wawasan pada PAUD inklusif di Nusa Tenggara Timur, juga untuk membantu penelitian di masa depan dalam menciptakan modelmodel praktis terbaik di lapangan.

Kata kunci: kemampuan berkomunikasi; anak-anak; gangguan emosi

\section{INTRODUCTION}

Young children are the cornerstone of every country's development that are needed to be taught, loved and care for. The stage of young children is called early childhood period. This early childhood period span from prenatal development until eight years of age (WHO, 2012). Investing in this period could enhance the overall quality of the person itself, for the rest of his/her lives. On the contrary, failure in fulfilling the young children' needs can bring disastrous, long-term effect to the person, including disabilities (UNICEF, 2013). This condition also affects those children with disabilities. One of the deciding factors that determines whether or not this period will serve as a positive foundation for a children with disabilities, is the proper development support addressed to them. That is the reason behind why both WHO and UNICEF have started a global agenda to address the need of care services for the children with disabilities all around the world.

Indonesia is one of the many countries that has started to put more attention for the development of the children with disabilities. The National Education System regulated in the Law Number 20 year 2003, has thoroughly organized the young children education system called PAUD 
(Pendidikan Anak Usia Dini) or Early Childhood Care and Development (ECCD) in english. This law specifically mentions that the purpose of the ECCD is to support the development of children aged $0-$ 6 years old by stimulating their physical and mental aspect in order to prepare them to enter formal education. The regulation is also covered in the law, which is to protect the rights of every children with disabilities in Indonesia to get a proper education services, which is also strengthened by the existence of the Child Protection Law Number 23 year 2002.

A decade after the existence of these regulations, Indonesia still finds itself struggling to fulfill the basic rights of young children with disabilities. In a rural and underdeveloped province such as East Nusa Tenggara, the problem has affected more than seven thousands children which then are unable to access decent care and education services (Seo, 2012). These children also suffered from various environmental risk factors that can worsen their developmental process mentioned by WHO (2012), such as poverty, stigma and discrimination, poor caregiver interaction, institutionalization, violence, abuse and neglect, and also limited access to program and care services.

There are various explanations on these environmental factors. Children in East Nusa Tenggara are prone to health conditions because of the low level of modern sanitation access. It is also the result of the existing belief, that using modern sanitation facilitation indicates that one is driven by shame ( $\mathrm{Li}$, Lassa, Talan, Sura, Banunaek, Frans \& Takesan, 2013). The shameness discourages the villagers from openly defecate in their residential areas, not because they realize that it is necessary for their health. This can cause problems because they will still defecate in an open area as long as nobody sees them. Poor ventilation and indoor smoke pollution from internal fires as the result of cooking in ume kbubu (traditional house of Dawan people, indigenous people of East Nusa Tenggara), is believed to play a part in poor respiratory health. However, the house is essential to the Dawan's ethnic identity and sense of psychological well being (Windi \& Whittaker, 2012). Malaria is also of at high risk in West Timor, which is urgent to be intervened (Walker, Wachs, Gardner, Lozoff, Wasserman, Pollitt \& The International Child Development Steering Group, 2007). Furthermore, indigenous children in West Timor these days are vulnerable to the practices of modern-slavery and human-trafficking. Driven by the motive to escape from these poor conditions, many children are sold or encouraged by their parents to work in Kupang city, or outside of Timor Island. These children are prone to violence and sexual abuse in their workplace (Li, Rahman, Boboy, Banunaek, Samid, Aviero \& Kiling, 2014).

In order to bring positive changes for young children with disabilities in East Nusa Tenggara, it is first needed to understand various condition and specific needs of young children with specific kind of disabilities. Emotional disorder (called tunalaras in Bahasa) is a disability that can be found early in 
human's life. Children with emotional disorder are considered 'troubled', 'conduct disordered' and 'disturbed' for their often hazardous behavior (Lewis \& Norwich, 2005). Previous study (Hadjstylianos, 2014) found that these children need a deep relationship, more participation from their parents, tutor and administrative side, also more nurturing behavior from the school.

To build a deep relationship, parents and tutor need to understand the development of these children' communication skills. Components of these skills are non verbal skills such as face expression, hand gestures, body gestures, and verbal skills such as language content, language structure and the utilizing of language (Porter, 2002). A proper descriptive qualitative study is needed to get a better understanding of the communication skills in young children with emotional disorder. Previous studies in Indonesia have put more focus in exploring the condition of young children without disabilities (Klaas \& Bunga, 2012; Bunga \& Klaas, in 2012) or older children with disabilities (Suparno, Supartini \& Purwandari., 2010; Berman, 2011; Kawuryan \& Raharjo, 2012). One project that aims older children with disabilities tried to improve the lives of children with disabilities in Flores Island, East Nusa Tenggara. The programs they implemented embrace the social model of disability approach and the CBR's approach, the activities also include livelihood support, inclusive education, and founding committees to help families. Some weaknesses found in the projects are: (1) Insufficient research prior to implementation; (2) Little understanding of CBR and disability from donor and the implementers; and (3) Close to none support from government for these rural communities whom suffering in extreme poverty and little access to basic services (Berman, 2011). Further efforts in describing skills and special needs of young children with disabilities are needed to prepare these children in East Nusa Tenggara to have a better support in terms of prevention and intervention programs.

This research aims to describe the communication skills of young children with emotional disorder in Kupang, East Nusa Tenggara. By understanding this and disseminate the result, the ECCD tutor, the parents and the community could get a better awareness of these children' needs. Enhanced awareness can then motivate them to include young children with disabilities in ECCD services. Such inclusive practice (Early Childhood Special Education/ECSE) has been proven in nurturing young children with disabilities in a developed country such as United States (Odom \& Wolery, 2003). In the future then, East Nusa Tenggara can aim to see more and more ECSE services grow and help to shape the development of young children with disabilities to their fullest potential. 


\section{METHODS}

\section{Design}

This research uses descriptive qualitative as its research design to address the research aim. Descriptive qualitative approach is different from phenomenology, grounded theory, and ethnography as it puts emphasis exclusively in descriptive domain. The approach was chosen because it allows the researchers to get thorough description of an experience or behavior (Sandelowski, 2000).

\section{Participant}

The subject to this research is almost 8 years old, female, and stays in Kupang city, East Nusa Tenggara. She is the fifth children in the family, the youngest one. She also has two older brothers and two older sisters. Her father works as a private company employee and her mother as a household mother. The distance between subject's house to her school is approximately 15 kilometers. Her mother always accompanies her to go to the school. She attends a special education school and is diagnosed by the school's expert as a children with emotional disorder.

\section{Procedure}

Data was gathered with direct observation and then compared to the data gathered from interviews with the subject's parents. Observation happened in the school setting, exactly when the subject was studying in the classroom and playing with friends in school time. Observation conducted five times, four times in school and one time in the subject's house. All activities were done in about two months duration. A checklist was used to observe structure of the language used, language utilization, content of the language, facial expression, also hand and body movement. Conversation with other children and playing time were two of events that is most carefully observed. Questions like "how does your child use language in daily activities?" and "how is your child's facial expression when she is communicating?" were asked to the child's mother. The questions were also asked to the child's father to conduct data triangulation.

\section{Analysis}

The observation checklist data was analyzed based on frequency of the behavior and special notes on these behaviors. The transcribed interview data were systematically coded using manual process, no data analysis software were used. The research team then performed content analysis to 
identify findings that emerged from informants. The identified findings were then used as complementary to the observation data. The research team met regularly to share impressions, synthesis findings and discuss alternate interpretations.

\section{ANALYSIS AND RESULTS}

The general findings of the observations are that the subject is actively playing alone, like to be alone and curious to an object that never seen before. The rest of the findings are encoded according to the communication skills explained by Porter (2002). The language structure expressed by subject was scrimpy. The subject was only able to express around five to six words in one sentence such as "I want (to go) buy (a) candy". The local language version was "Beta mo (pi) beli (sabungkus) gula(-gula)", while the Indonesian version was "Saya mau (pergi) membeli (sebungkus) gula(-gula)". The sentences were often incomplete and other persons that unfamiliar with subject could find these sentences hard to understand. For example mentioning only "gula" would mean "sugar", mentioning "gula-gula" would means "candy". Subject often avoided to explain the purpose of her sentences if required.

Subject used her mother tongue, Kupang city language, mostly influenced by her mother. She also used the language dialect consistently and fluently. It was found that subject has a small range of vocabularies. She often used same sentences to express a slightly different message. This also could be confusing to her new acquaintance. Subject happened to be in the same class with students with hearing difficulties/impairment. According to her mother, this situation made the subject's capability in using sentences and expanding her vocabulary is worsened. The content of subject's language is mainly straight forward and almost every time purposive. It was rarely found abusive or meaningless sentences. This was corrected by the interview result that described that subject's contents of language were mostly direct and did not have complex meaning such as quoted below:

"My daughter always says things in straight way and easy to understand, like in asking toys, asking for play, want to eat, and many more. I don't know, um, maybe she learned it from me? Hahaha.."

"Be(ta) pung anak selalu omong ini lurus-lurus terus ju gampang mo mangarti, kek minta mainan dong, minta main, mo makan... terus banyak le yang lain. Beta son tahu, mangkali juga dia belajar dari beta? Hahaha..." (local language version). 
"Anak saya selalu ngomong lurus dan mudah dimengerti, seperti minta mainan-mainan, lalu minta bermain, mau makan... lalu banyak lagi yang lain. Saya tidak tahu, mungkin juga dia belajar dari saya? Hahaha..." (Indonesian version).

Observation and interview data shows that subject has no trouble in expressing basic human emotions such as happy, shy and sad. Her facial expression could clearly understand by regular persons with no difficulties. This non verbal language becomes the main way of communication of the subject, rather than talking. This is helpful according to her mother, because her emotion expressions are easier to understand. Children's environment like closeness to parents might play part in improving subject's pragmatic language skills.

Subject was very active in using her hands as a way to communicate, but rather in unique way, by drawing something. She loves to draw the object(s) of her language content in the mud. One example observed, subject often asked for her backpack to her mother by drawing backpack on the ground, not by saying any command. This rather bossy attitude was confirmed by interview data from her mother:

"Well she often does that (drawing pictures in the mud) to express her needs, perhaps it is because that she is still don't know the best way to communicate with other person, especially adults. I think we as parents need to teach them more in regards of this."

"Ya itu su dia sering bekin tu (gambar di tanah) buat kasih tunjuk dia pung kebutuhan, mangkali ju karena dia masih belum terlalu tahu cara yang paling bae buat baomong deng orang lain, apalai dengan orangtua dong. Beta pikir ktong sebagai orangtua perlu buat ajar-ajar dong dalam hal ini." (local language version).

"Iya dia sering lakukan itu (gambar di tanah) untuk tunjukkan kebutuhannya, mungkin karena dia masih belum tahu cara yang paling baik untuk berkomunikasi dengan orang lain, terutama orangtua. Saya pikir kita sebagai orangtua perlu untuk mengajar mereka dalam hal ini." (Indonesian version).

\section{DISCUSSION}

Subject's difficulties in language structure and also using language itself strengthen the result of Mackie and Law (2010) study that mentioned 94\% $(n=15)$ of children with emotional disorder were experiencing difficulties in structural language, pragmatic language and word decoding. According to the result, subject was found to be lacking of ability to have meaningful sentences. This finding 
confirms the review from Benner, Nelson and Epstein (2002) that explains children with emotional and behavioral disorder were deficient in expressive language and receptive skills.

Observation and interview data shows that subject has no trouble in expressing basic human emotions such as happy, shy and sad. Her facial expression can clearly be understood by regular persons with no difficulties. This non verbal language becomes the main way of communication of the subject, rather than talking. This is helpful according to her mother, because her emotion expressions are easier to understand. The findings somehow different to the study conducted by Mackie and Law (2010) that finds pragmatic language is one of the difficulty problem that children with emotional disorder have.

Subject was often found to use more of her hands in communicating, rather than using words, for example to draw what was being communicated by her in the mud. This trouble in expressing wants with hand and body gestures were similar to Hill and Coufal (2005) research that retrospectively examined and found that children with emotional disorder would have difficulties in body expression for communication use.

Young children with emotional disturbances are potential trouble-makers if not be intervened early, they could wreak havoc in the community in terms of conducting various anti-social activities (Davis, Banks, Fisher, Gershenson \& Grudzinskas, 2007). This disruptive and destructive tendency has only shown in this research subject specifically in the active behavior with a tendency of attention deficit hyperactivity disorder. This is an issue that should be addressed immediately since children with conduct disorder faces various challenges to develop properly. Utilization of various disciplining technique will be useful instead of classic indigenous way of discipline, in example using corporate punishment. The parent of these children should be told how to apply discipline in their home setting, in order to modify behavior without damaging children's emotional development and attachment.

Young children with emotional disorders normally will not experience any atypical language development that experienced by children with hearing, vision, intellectual or motor impairments. Sometimes though, a language delay could be happened whenever a child with emotional disability is required to study more than one language simultaneously (Porter, 2002). In the subject cases, it might be necessary to limit them to one language at a time. This is where the role of parent and also teacher become important, that is in controlling the use of language in child's daily activities. Coordination between both stakeholders is also important to avoid confusion in children process of learning language. 
Subject's tendency to deliver straight forward message with her non verbal expression was strengthened with the learning environment in her school, where students with different kind of disabilities are mixed into the same class. According to Hester, Baltodano, Hendrickson, Tonelson, Conroy and Gable (2004), school inability and rather neglectful attitude to help students with emotional disabilities to succeed in the development could turn them into a burden in the future for the community. This should be anticipated by first increasing the awareness of the tutors and parents about their student's development.

As the result, subject as a young child with emotional disorder has a shallow verbal proficiency and has tendency to put more emphasis in communicating with others by using the non-verbal skill set. Parents and tutor that involved with children with emotional disorders should consider this condition when interacting with the children. Stimulating the verbal communication skills will bring balanced communication ability to the children, making them more sociable. A more sociable child hopefully will reduce their problematic behavior.

The limitation of this study is researcher have not been able to conduct a longer observation in participant's behavior since the participant was entering her eight years of life, which means she was not longer in early childhood period. Another limitation is that the fact that is only one subject participated in this study, results in limited resources and time from the researcher team. A longer duration of research and larger pool of participants could help to improve similar research in the future.

\section{CONCLUSION AND SUGGESTIONS}

\section{Conclusion}

This study describes the communication ability of young children with emotional disorder. By understanding the components of communication skills in young children with emotional disorder, parents and ECCD tutors should start to build a better stimulating environment for their children's communication development. According to the findings the expected improvement in the children with emotional disorder will be achieved if the practice stresses more on enhancing their verbal communication ability, such as language content, language structure and the uses of language. The balance between verbal and non verbal communication skills hopefully will help children to adjust with the social environment in the future. 


\section{Theoretical Suggestions}

This research aimed to describe the communication skills in young children with emotional disorder. More rigorous qualitative research is needed to develop a theoretical model that is built inductively from the process and meaning behind communication skills of young children with emotional disorder. Researcher could also build a theoretical framework by doing statistic testing of communication skills and its related aspects. A strongly composed theory will help in designing appropriate interventions to help children with emotional disorder's development.

Future researches should also aim to do further study in describing another skills or behaviors of young children with emotional disorder or in another kind of disability such as hearing impairment. In addition, future researchers may aim to expand their study purpose: it is to establish intervention that is addressed for young children with disabilities. These kind of studies will enrich the existing knowledge about children's disability and will eventually contribute to a global model to support development of young children with emotional disorder all over the world.

\section{Practical Suggestions}

Collaboration between tutors and parents could encourage more inclusive ECCD/ECSE to work effectively in bridging the gap between children with and without disabilities. Empowering local resources, such as integrated health posts and religious services for young children, could also help to create a stimulating environment for young children with disabilities.

\section{REFERENCES}

Benner, G. J., Nelson, J. R., \& Epstein, M. H. (2002). Language skills of children with EBD: A literature review. Journal of Emotional and Behavioral Disorders, 10(1), 43-59.

Berman. L. (2011). Integrating disability into development in Eastern Indonesia. Health, Culture and Society, 1(1), 133-145.

Bunga, B. N., \& Klaas, M. A. N. (2012). The role of traditional games Kayu Do'I in child counseling processes. In S. Kartadinata. (Ed) The $1^{\text {st }}$ International Seminar on Guidance and Counseling (ISGC), (pp. 63-72). Yogyakarta: UNY.

Davis, M., Banks, S., Fisher, W., Gershenson, B., \& Grudzinskas, A., Jr. (2007). Arrests of adolescent clients of a public mental health system during adolescence and young adulthood. Psychiatric 
Services, 58(11), 14-54.

Ganur, M. H., Bunga, B. N., \& Kiling, I. Y. (2014). Pola komunikasi anak usia dini tunarungu bukan bawaan. Jurnal Transformatif Edukasi, 3(2), 63-69.

Hadjstylianos, E. (2014). Exploration of effective strategies for children with emotional disorders as identified by helping professionals in schools. North American Journal of Psychology, 16(1), 129-136.

Hester, P. P., Baltodano, H. M., Hendrickson, J. M., Tonelson, S., Conroy, M. A., \& Gable, R. A. (2004). Lessons learned from research on early intervention: What teachers can do to prevent children's behavior problem. Preventing School Failure, 49(1), 5-10.

Hill, J. W., \& Coufal, K. L. (2005). Emotional/behavioral disorders: A retrospective examination of social skills, linguistics, and student outcomes. Communication Disorders Quarterly, 27, 33-46.

Kawuryan, F., \& Raharjo, T. (2012). Pengaruh stimulasi visual untuk meningkatkan kemampuan membaca pada anak disleksia. Jurnal Psikologi Pitutur, 1(1), 9-20.

Klaas, M. A. N., \& Bunga, B. N. (2012). The function of traditional games Siki Doka in guidance and counseling: A cross-cultural study. In S. Kartadinata. (Ed) The $1^{\text {st }}$ International Seminar on Guidance and Counseling (ISGC), (pp. 49-54). Yogyakarta: UNY.

Lewis, A. \& Norwich, B. (2005). Special teaching for special children? Pedagogies for inclusion. Berkshire: Open University Press.

Li, D. E., Lassa, J. A., Talan, J., Sura, Y. B., Banunaek, R., Frans, N., \& Takesan, I. (2013, July). Future of Latrines and the Future of Civilization: Understanding Cultural Barriers and Opportunities in West Timor: An anthropological Survey of Sanitation in West Timor, Indonesia [PDF]. Kupang: Institute of Resource Governance and Social Change.

Li, D. E., Rahman, A., Boboy, J., Banunaek, R., Samid, R. S., Aviero, G., Kiling, I. Y. (2014). Human trafficking report: Human slavery in modern Indonesia. Institute of Resource Governance and Social Change. Ditemu kembali dari http://www.irgsc.org/slavery-in-indonesia.html

Mackie, L., \& Law, J. (2010). Pragmatic language and the child with emotional/behavioural difficulties (EBD): A pilot study exploring the interaction between behavior and communication disability. International Journal of Language and Communication Disorders, 45(4), 397-410.

Odom, S. L. \& Wolery, M. (2003). A unified theory of practice in early intervention/early childhood special education: Evidence based practices. The Journal of Special Education. 37(3), 164-173.

Porter, L. (2002). Educating young children with additional needs. Crows Nest: Allen \& Unwin.

Sandelowski, M. (2000). Whatever happened to qualitative description? Research in Nursing \& Health, 
23, 334-340.

Seo, Y. (2012, 24 April). Ribuan anak cacat NTT tak mengenyam pendidikan. Tempo. Ditemu kembali dari http://www.tempo.co/read/news/2012/04/24/079399414

Suparno, Supartini, E., \& Purwandari. (2010). Pengembangan model modifikasi perilaku sosial melalui media belajar berkonsep konvergensi bagi anak autis. Jurnal Kependidikan, 40(2), 201-214.

United Nations Children's Fund (2013). The state of worlds's children 2013: Children with disabilities. Ditemu kembali dari http://www.unicef.org/sowc2013/

Walker, S. P., Wachs, T. D., Gardner, J. M., Lozoff, B., Wasserman, G. A., Pollitt, E. \& the International Child Development Steering Group. (2007). Child development: Risk factors for adverse outcomes in developing countries. Lancet, 369, 145-147.

World Health Organization (2012). WHO and UNICEF encourage discussion and action on early childhood development and disability: A discussion paper. Ditemu kembali dari http://ww.who.int/disabilities/media/news/2012/13_09/en/

Windi, Y. K. \& Whittaker, A. (2012). Indigenous round houses versus 'healthy houses': Health, place and identity among the Dawan of West Timor, Indonesia. Health \& Place, 18, 1153-1161. 